Психолого-педагогічні проблеми становлення сучасного фахівця Випуск 2018

УДК 37.016:808.1(083.742):37.046"465*7/11"

DOI 10.26697/9786177089017.2018.299

(C) Вітюк В. В., Зуйко К. В., 2018

Вітюк Валентина Володимирівна

Східноєвропейський національний університет імені Лесі Українки

Зуйко Катерина Вікторівна

Східноєвропейський національний університет імені Лесі Українки

\title{
СПЕЦИФІКА УРОКІВ ЛІТЕРАТУРИ РІДНОГО КРАЮ У ПОЧАТКОВІЙ ШКОЛІ
}

У статті проаналізовано особливості уроків літератури рідного краю, висвітлено їх дидактичні можливості для розвитку інтересу до читання у молодших школярів. У науковій розвідиі визначено найбільш ефективні традиційні та інноващійні форми, методи $і$ прийоми навчання під час вивчення літератури рідного краю: зустріч із літераторами, екскурсія до музею письменника, віртуальна мандрівка, презентація книг місиевого письменника, написання листа письменнику вдячного або обуреного читача, заповнення анкети літературного героя, створення кейс-стадi, скрапбука письменника.

Ключові слова: уроки літератури рідного краю, кейс-стаді, скрапбук письменника.

Проблема, їі зв'язок із важливими науковими чи практичними завданнями. Спостереження за освітнім процесом у початковій школі засвідчують, що в сучасних умовах глобальної комп'ютеризації суспільства у більшості молодших школярів поступово зникає інтерес до читання. Внаслідок цього перед сучасною школою ставляться завдання, спрямовані на розвиток зацікавленості в учнів до читання художньої та науково-популярної літератури в умовах інформаційного навчального середовища.

Аналіз публікацій (виділення невирішених проблем). Питання про необхідність впровадження уроків літературного краю в освітній процес порушували у наукових працях сучасні ученіметодисти Н. Й. Волошина, В. Я. Неділько, С. О. Пультер, Б. І. Степанишин та інші.

Ціль статті - проаналізувати особливості уроків літератури рідного краю, їх дидактичні можливості для розвитку інтересу до читання у молодших школярів, визначити найбільш ефективні традиційні та інноваційні форми, методи і прийоми навчання під час вивчення літератури рідного краю.

Виклад основного матеріалу, обгрунтування результатів дослідження. Література рідного краю $€$ важливим складником 


\section{Збірник наукових статей}

літературної освіти, що охоплює твори письменників, пов'язаних із регіоном, у якому розташований навчальний заклад.

Уроки літератури рідного краю подібні до уроків позакласного читання тим, що вони насичені за змістом, учитель сам обирає твори для обговорення, діти читають їх у позаурочний час, а навчальний матеріал не висвітлено у шкільному підручнику. Особливістю уроків літератури рідного краю є добір різного матеріалу для вивчення, адже у кожній місцевості жили і творили різні письменники. Аксіологічною основою кожного такого заняття $є$ патріотизм: любов до України починається 3 любові до малої батьківщини, поваги до ії культури. Учитель початкової школи повинен знати, хто 3 письменників народився, жив чи живе на малій батьківщині учнів, які визначні твори тут написано, хто з митців тут похований, як відбувається сучасний літературний процес.

Найкраща форма проведення уроку літератури рідного краю зустріч із літераторами, які мешкають у місті чи селі, де розташована школа. Вони читають власні твори, розповідають про себе, діляться 3 учнями задумами, історіями написання творів. Під час цих зустрічей учні мають нагоду зрозуміти психологію творчості, зазирнути у творчу лабораторію письменника, осмислити процес творення мистецтва слова.

Уроки літератури рідного краю активізують життєвий досвід дитини. Найбільше їх здебільшого цікавить період життя письменників не лише тих, хто народився і творив у цьому краї, а й, наприклад, видатні письменники, які певний час жили й творили на території батьківщини маленького читача, особливо, якщо вони написали у цьому краї твори, що розповідають про письменника. Наприклад, Волинь у життєвому і творчому шляху Лесі Українки.

Завдання вчителя початкової школи - максимально наблизити літературу до життя учнів. Молодші школярі збирають твори про свою малу батьківщину, розповідають на уроці про них однокласникам, зіставляють пейзажі в художньому тексті 3 реальним довкіллям, досліджують мистецьку специфіку словесних образів і т. ін.

Готуючись до уроків літератури рідного краю, учні виконують такі завдання: ознайомитись у бібліотеці 3 книгами і місцевими періодичними виданнями, в яких надруковано твори письменника, прочитати їх; побувати в місцях рідного краю, пов'язаних із життям літератора, скласти розповідь на основі відвіданого; зібрати цікавий матеріал про письменника i укласти його в літературну карту; підготувати антологію віршів про рідний край.

Уроки літератури рідного краю органічно поєднані 3 краєзнавством, історією та культурою батьківщини. Учні мають відчути себе спадкоємцями національної культури, адже письменники, 
які тут народилися, жили, боролися за право народу бути самим собою, розмовляли, писали українською мовою. Вивчення літератури рідного краю наближує творчість письменника до молодшого школяра. Митець втрачає свою хрестоматійну іронічність, перетворюючись на краянина. Робота 3 матеріалами музею, місцевою пресою, бібліографічний пошук, літературні подорожі рідним краєм, зустрічі 3 письменниками-сучасниками, зіставлення літературних образів із буденною реальністю роблять уроки літератури рідного краю незвичними та пам'ятними для молодших школярів.

Цілком погоджуємось із думкою О. Ісаєвої про те, що «завдання методики навчання літератури сьогодні полягає у тому, щоб поєднати «класичні» підходи засвоєння знань із сучасними комп'ютерними засобами» [1, с. 4]. На нашу думку, забезпечити належний рівень навчання літератури рідного краю в початковій школі можливо за умови умілого поєднання традиційних та інноваційних технологій навчання.

Особливістю уроку літератури рідного краю є те, що вчитель початкової школи має провести зустріч дитини з художнім текстом як мистецьким явищем 3 метою його цілісного сприйняття, на прикладі художнього тексту формувати естетичні почуття, переконання, світогляд, риси характеру, розвивати інтелект, емоції, творчі здібності молодших школярів. Істотне значення для підвищення ефективності уроку мають правильно дібраний літературно-краєзнавчий матеріал та сучасні педагогічні технології навчання.

Оскільки Волинь нині має більше двох десятків лише дитячих письменників [2], то варто розглядати їх творчість на уроках літератури рідного краю, під час виховних годин, проводити літературні вечори, презентації книг місцевого письменника, зустрічі 3 сучасними письменниками, віртуальні мандрівки, екскурсії до музею письменника (Лесі Українки) і т. п.

Цілком погоджуємось зі словами Й. Гете: «Хто хоче розуміти поета, мусить піти в поетову країну». Екскурсія є одним із ефективних способів зацікавити молодших школярів літературою, іiі творцями. Якщо ж немає можливості відвідати музей, доцільно провести віртуальну мандрівку. У будь-якому випадку літературні екскурсії не повинні мати пасивний характер. Учні повинні осмислити, зрозуміти i закріпити в пам'яті все побачене. Рекомендовані форми роботи після відвідин музею: 1) обмін враженнями; 2) оформлення фотовиставки за матеріалами екскурсії; 3) написання відгуку до шкільної газети; 4) рекламування книг письменника; 5) проведення вікторини за життєписом і творчістю письменника; 6) презентація мультимедійних проектів тощо. 


\section{Збірник наукових статей}

Ефективними прийомами під час вивчення літератури рідного краю $\epsilon$ написання листа письменнику вдячного або обуреного читача, заповнення анкети літературного героя, створення кейс-стаді (або ситуаційне завдання), скрапбука письменника. Інноваційними прийомами є кейс-стаді та скрапбук.

Кейс-стаді - це прийом ситуаційного навчання, максимально наближеного до життя. Для осмислення реальної життєвої ситуації актуалізується комплекс знань, набутого життєвого досвіду. Наприклад, після прочитання художнього твору визначити власну позицію - як би я себе поводив, якби головний герой був моїм другом? Відповідь аргументуйте. Або, прочитавши початок повісті Миколи Онуфрійчука «Дівчина 3 бантиком», уявіть себе на місці головної героїні, подумайте і скажіть, як би ви вирішили проблему з Рябчиком? А як ви думаєте, що зробила Наталка? Про це ми дізнаємось прочитавши наступний розділ повісті. Цікаво, чи збіглись ваші рішення, чи було у них щось спільне? Чиє рішення було більш вдалим, кращим для всіх?

Скрапбук письменника - це прийом оригінально оформлених життєвих і творчих відомостей письменника, так як скрапбукінг - це мистецтво оригінального, декоративного оформлення альбому історії, щоденника тощо.

У наш час на уроках літературного читання можна використовувати багату палітру засобів інформаційно-комп'ютерних технологій: мультимедійні презентації, електронні книги, журнали, довідково-інформаційні джерела, навчальні фільми і т. ін.

Належний рівень обізнаності вчителя початкової школи щодо застосування інноваційних технологій забезпечить якісну та ефективну методику навчання літературного читання. Адже на уроках літературного читання вчитель передусім має справу 3 мистецтвом слова, працює над розвитком мовлення, залучає учнів до духовності й естетичних цінностей. Проблема лише в тому, що, на жаль, процес використання інноваційних технологій у процесі вивчення літератури має епізодичний, фрагментарний характер. Тому необхідно сформувати системний цілісний підхід до застосування інноваційних технологій на уроках вивчення літератури рідного краю.

Проаналізувавши психолого-педагогічні особливості учнів початкової школи, яким притаманне конкретно-образне мислення, ми дійшли висновку, що результативність формування читацьких інтересів підвищиться, якщо на уроках літературного читання застосовувати інформаційно-комп'ютерні технології, виконані як добре відомими програмними засобами - Microsoft Power Point, так i спеціалізованими редакторами - Macro media Flash, Picasa, Photodex ProShow. Використання мультимедійної дошки забезпечує нові шляхи 
Психолого-педагогічні проблеми становлення сучасного фахівця Випуск 2018

подачі інформації, економить час вчителя на уроці, підвищує ефективність презентації методичного матеріалу, дозволяє зберігати необхідну інформацію у пам'яті комп’ютера 3 можливістю подальшого відтворення. Використання на уроках літератури рідного краю інформаційно-комп'ютерних технологій сприяє покращенню запам'ятовування образу письменника; формуванню у молодших школярів повноцінної навички розуміння літературного твору; покращенню запам'ятовування змісту літературного твору; чіткому усвідомленню жанрових особливостей твору; підвищенню продуктивності навчання, оскільки одночасно задіяні зоровий i слуховий канали сприйняття інформації.

Застосування різних аудіовізуальних засобів (музики, графіки, анімації) підвищує у молодших школярів мотивацію до читання творів письменників рідного краю; ознайомлює учнів початкової школи 3 дитячою літературою письменників Волині (оскільки шкільні бібліотеки такою літературою не в повній мірі забезпечені); забезпечує виховання у дітей соціальних, морально-етичних цінностей через презентації художніх образів літературних творів письменників рідного краю; пробуджує інтерес до пізнання рідного краю, творчості місцевих дитячих письменників. Проте варто наголосити, що інформаційно-комп'ютерні технології - це лише один із засобів навчання, тому недоцільно презентацію робити важливішою за урок, штучно «підганяти» весь урок під презентацію, використання на уроці інформаційно-комп'ютерних технологій не змінює ні типу уроку, ні його структури.

Варто також наголосити, що якою б привабливою не була навчальна діяльність із використанням комп'ютера на уроках літературного читання, необхідно суворо дотримуватися встановлених санітарних норм для учнів початкової школи.

Висновки. Отже, на уроках літературного читання можна використовувати різні форми, методи, прийоми і засоби навчання, головне - щоб перед учнями уявно постав письменник, щоб він, так би мовити, зайшов до класу і щоб учні своїм внутрішнім, духовним зором побачили його вираз обличчя, збагнули його вдачу, характер, переконання. А коли письменник стане зрозумілою, близькою учневі людиною, тоді й виникне у молодших школярів інтерес до читання. Урок літератури рідного краю може бути як традиційним, так i нестандартним. Важливо не це. Важливо, щоб інноваційні технології не затіняли змісту уроку, а навпаки, будили думку і почуття учня, спонукали трудитися його душу. 


\section{Література}

1. Ісаєва О. Комп'ютер на уроці літератури як методична проблема / О. Ісаєва // Всесвітня література в середніх навчальних закладах України. - 2009. - № 5. - С. 2-5.

2. Вітюк В. В. Сучасна література Волині для дітей: хрестоматія для учнів початкової школи / В. В. Вітюк, О. К. Данилюк. - Луцьк : ПП Іванюк В. П., 2015. - 400 с.

Валентина Витюк, Катерина Зуйко. Специфика уроков литературы родного края в начальной школе.

В статье проанализированы особенности уроков литературы родного края, рассмотрень их дидактические возможности для развития интереса к чтению у младших икольников. В научной разведке определены наиболее эффективные традиционные и инновационные формы, методы и приемы обучения при изучении литературы родного края: встреча с литераторами, экскурсия в музей писателя, виртуальное путешествие, презентация книг местного писателя, написание письма писателю благодарного или возмущенного читателя, заполнение анкеты литературного героя, создание кейсстади, скрапбука писателя.

Ключевые слова: уроки литературы родного края, кейс-стади, скрапбук писателя.

Valentyna Vityuk, Kateryna Zuiko. The specification of Native Literature Lessons in Primary School.

In the article the peculiarities of Native Literature Lessons are analyzed and didactic opportunities to reading interest development of primary pupils are reflected. In scientific field the most effective traditional and innovational forms, methods and techniques during the learning of Native Reading are determined, such as: the meetings with authors, the excursion to the writer's museum, virtual trip, book presentation of a local writer, the letter writing of a pleased or angry reader, the character characteristics form filling, creation of case-study or scrapbook of the writer.

Keywords: Native Reading Lessons, case-study, writer's scrapbook.

Стаття надійшла до редакційної колегії 14.05.2018 Прийнято до друку 14.05.2018

\section{Інформація про авторів:}

Вітюк Валентина Володимирівна - кандидат педагогічних наук, доцент кафедри філології та методики початкової освіти, Східноєвропейський національний університет імені Лесі Українки. Зуйко Катерина Вікторівна - магістр, Східноєвропейський національний університет імені Лесі Українки. 